NBSIR 81-2321

\title{
Single-Room Heat Balance for Building Heat Transfer
}

U.S. DEPARTMENT OF COMMERCE

National Bureau of Standards

National Engineering Laboratory

Center for Building Technology

Washington, DC 20234

November 1981

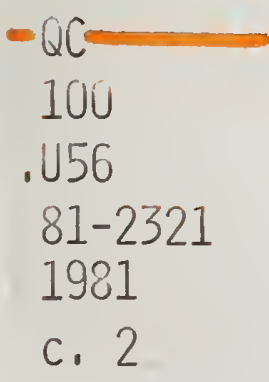

Sponsored by:

Department of Energy

Passive and Hybrid Solar Energy Division

Office of Solar Heat Technologies

Washington, DC 20585 



\section{SINGLE-ROOM HEAT BALANCE FOR BUILDING HEAT TRANSFER}

B. A. Peavy

U.S. DEPARTMENT OF COMMERCE

National Bureau of Standards

National Engineering Laboratory

Center for Building Technology

Washington, DC 20234

November 1981

Sponsored by:

Department of Energy

Passive and Hybrid Solar Energy Division

Office of Solar Heat Technologies

Washington, DC 20585

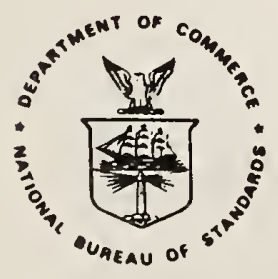

U.S. DEPARTMENT OF COMMERCE, Malcolm Baldrige, Secretary NATIONAL BUREAU OF STANDARDS, Ernest Ambler, Director 


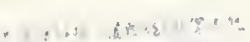

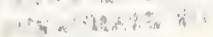
और $x$ is

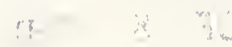


1. INTRODUCTION $\ldots \ldots \ldots \ldots \ldots \ldots \ldots \ldots \ldots \ldots \ldots \ldots \ldots \ldots \ldots \ldots \ldots \ldots \ldots \ldots \ldots \ldots$

2. RADIATION AND RADIOSITY SHAPE FACTORS ...................... 2

3. CONVECTION HEAT TRANSFER BETWEEN ROOM SURFACES AND AIR .......... 4

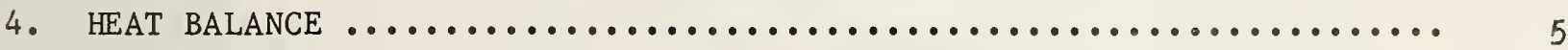

5. CONCLUSIONS $\quad \ldots \ldots \ldots \ldots \ldots \ldots \ldots \ldots \ldots \ldots \ldots \ldots \ldots$

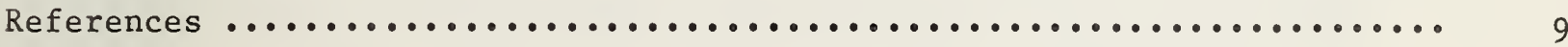

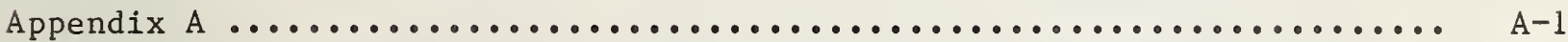




$$
\begin{aligned}
& A=\text { surface areas } \\
& B=\text { constants } \\
& C_{p}=\text { specific heat of air } \\
& C=\text { cloud cover } \\
& \begin{aligned}
\mathrm{H}_{i, t}^{\mathrm{m}} \mathrm{H}_{\mathrm{o}, t}^{\mathrm{m}}= & \begin{array}{l}
\text { inside and outside coefficients of heat transfer for } \\
\text { building construction } m \text {, at time } t
\end{array}
\end{aligned} \\
& \mathrm{H}_{\mathrm{ci}}^{\mathrm{m}}=\text { convection coefficient of heat transfer for building } \\
& \text { construction } \mathrm{m} \\
& \mathrm{H}_{\mathrm{a}}=\text { coefficient of heat transfer between room air and simulated } \\
& \text { room mass } \\
& \mathrm{R}_{\mathrm{n}}^{\mathrm{m}}=\text { factors of past heat } \mathrm{flux} \text { history for building construction } \\
& S_{i, t}^{m}=\text { sum of resultant radiative internal heat gains ( } f l u x \text { ) and } \\
& \text { transmitted solar energy to inside surface of building } \\
& \text { construction, m } \\
& \mathrm{T}_{i, t}^{\mathrm{m}}, \mathrm{T}_{\mathrm{o}, t}^{\mathrm{m}}=\text { inside and outside surface temperature for building } \\
& \text { construction } \mathrm{m} \text {, (wall, ceiling, floor, window or door), } \mathrm{m}=1 \text {, } \\
& 2,3 \ldots \text { n total number of room surfaces } \\
& Q_{i, t}^{m}, Q_{o, t}^{m}=\text { heat } f l u x \text { at inside and outside surface of building } \\
& \text { construction, } m \text { at time } t \\
& Q_{f}=\text { sum of resultant convective internal heat gains at time } t \text {. } \\
& \mathrm{X}_{\mathrm{n}, \mathrm{k}}^{\mathrm{m}}, \mathrm{Y}_{\mathrm{n}, \mathrm{k}}^{\mathrm{m}}, \mathrm{Z}_{\mathrm{n}, \mathrm{k}}^{\mathrm{m}}=\mathrm{k} \text { th order conduction transfer function for building } \\
& \text { construction, } \mathrm{m}, \mathrm{n}=1,2,3 \ldots \\
& \alpha_{\mathrm{m}}=\text { absorptance of surface } \mathrm{m} \\
& I_{t}^{m}=\text { incident solar radiation on surface } m \\
& \beta=\text { long-wave radiation factor } \\
& \mathrm{F}_{\mathrm{m}, \mathrm{n}}=\text { radiosity shape factor, seeing surface } \mathrm{m} \text {, to receiving } \\
& \text { surface } n \\
& \mathrm{~T}_{\mathrm{b}, \mathrm{t}}=\text { outdoor air temperature at time, } \mathrm{t} \\
& \mathrm{T}_{\mathrm{a}, \mathrm{t}}=\text { room air temperature at time } \mathrm{t} \\
& \mathrm{T}_{\mathrm{c}, \mathrm{t}}=\text { surface temperature of simulated room mass } \\
& \mathrm{V}_{\mathrm{o}, \mathrm{t}}=\text { mass flow of infiltration air to room } \\
& \mathrm{V}_{\mathrm{a}, \mathrm{t}}=\text { mass flow of supply air to room }
\end{aligned}
$$


Single-Room Heat Balance for Building Heat Transfer

by

B. A. Peavy

\section{ABSTRACT}

A single-room heat balance has been developed to provide a more precise computational tool. The primary purpose for this tool is to evaluate the effects of approximations presently used in computer programs on the determination for building heating and cooling loads. Specific algorithms to be incorporated in the room heat balance concern radiosity shape factors, temperature difference dependent convection heat transfer coefficients, simulated room mass, and an iterative methodology for solution of room temperatures.

Keywords: building heating/cooling loads; heat balance for a single room; heat transfer; radiosity shape factors. 


\section{INTRODUCTION}

Fundamental to the determination of heating and cooling loads in buildings is the formulation of a heat balance for a single room within a building. Items to be considered as elements of the heat balance are discussed briefly:

1. Conduction heat transfer in building constructions such as through the solid interior surfaces of ceilings, floors, walls, windows, doors, etc. as affected by temperature changes at their exterior surfaces.

2. Radiation heat transfer by emitted and reflected energy among the room surfaces.

3. Convection heat transfer between room air and the room surfaces.

4. Distribution and magnitude of transmitted solar radiation passing through fenestration areas.

5. Heat generation within the room and the resultant convection and radiation heat transfer.

6. Heat transfer to room mass such as furniture, furnishings, etc. This is to be considered with changes in room air temperature only.

7. Convection heat and mass transfer from sources and/or forces acting exterior to the room such as infiltration, exfiltration, circulating air, and inter- and intra-room convective air motion.

A fairly thorough discussion of the above items is found in Kusuda [1], and the heat balance equation involving most of the above items has been incorporated in the computer program NBSLD [2]. In this paper, algorithms will be developed for items 2 and 3, heat balance equations will be derived using the seven items listed above, and a method will be proposed for solving the resulting set of equations using an iterative technique. 


\section{RADIATION AND RADIOSITY SHAPE FACTORS}

The algorithms for calculating radiation shape factors are found in [2] and include angle-factor algebra and solutions for determining shape factors between a plane rectangular surface of arbitrary dimension and another parallel or perpendicular rectangular plane surface.

Radiosity is defined as the total radiant flux leaving the surface of a system and includes both energy emitted and energy reflected from a system. Radiosity shape factors for room surfaces are computed using Hottel's method [3] for a gray enclosure, and are determined from the radiation shape factors and the areas and emittances of the separate surfaces. Radiosity shape factors will be used in the same manner for room heat balances as radiation shape factors are presently used in NBSLD. One difference is that the room surfaces will be able to "see" themselves due to reflection. Another difference will be that the emittance of the seeing surface will be incorporated in the shape factors. Hottel's method is preferred for the transient numerical analysis of a complete system, particularly where the surface temperatures are unknown.

A subroutine has been developed for calculating radiation and radiosity shape factors between inside rectangular surfaces of a room. It was developed for accepting data in a form similar to Data Sheets 12, 13 and 14 (with slight modifications) of the computer program NBSLD [2]. For computing radiation shape factors, the exact location of a window, door or secondary wall must be defined, in addition to the respective areas and emittances. This is different from present practice, where only the area is defined for windows, doors and secondary walls.

At present, the program is designed to calculate factors for rooms with walls containing different building constructions or surface coverings. The program presently does not include more than one surface for either the floor or ceiling. Consequently, floors with two or more surface coverings such as wood, tile and rug combinations are modeled as one surface, and skylights in a ceiling are not modeled. In its present form, the program can accept data for 30 rectangular surfaces placed either parallel or perpendicular to each other, including ceiling, floor, 4 primary walls and a collection of up to 24 windows, doors and secondary wall sections located on the four walls. A simulated room layout is shown in figure 1 , which illustrates the sequence of surfaces and necessary measurements needed for calculation of radiation shape factors.

Appendix $\mathrm{A}$ is a listing of the subroutine needed for determining the radiation and radiosity shape factors for use with NBSLD, as well as the necessary additional information needed for Data Sheets 13 and 14 of reference 2 . The integration of the radiosity shape factor into the room heat balance will be discussed in section 4 . 


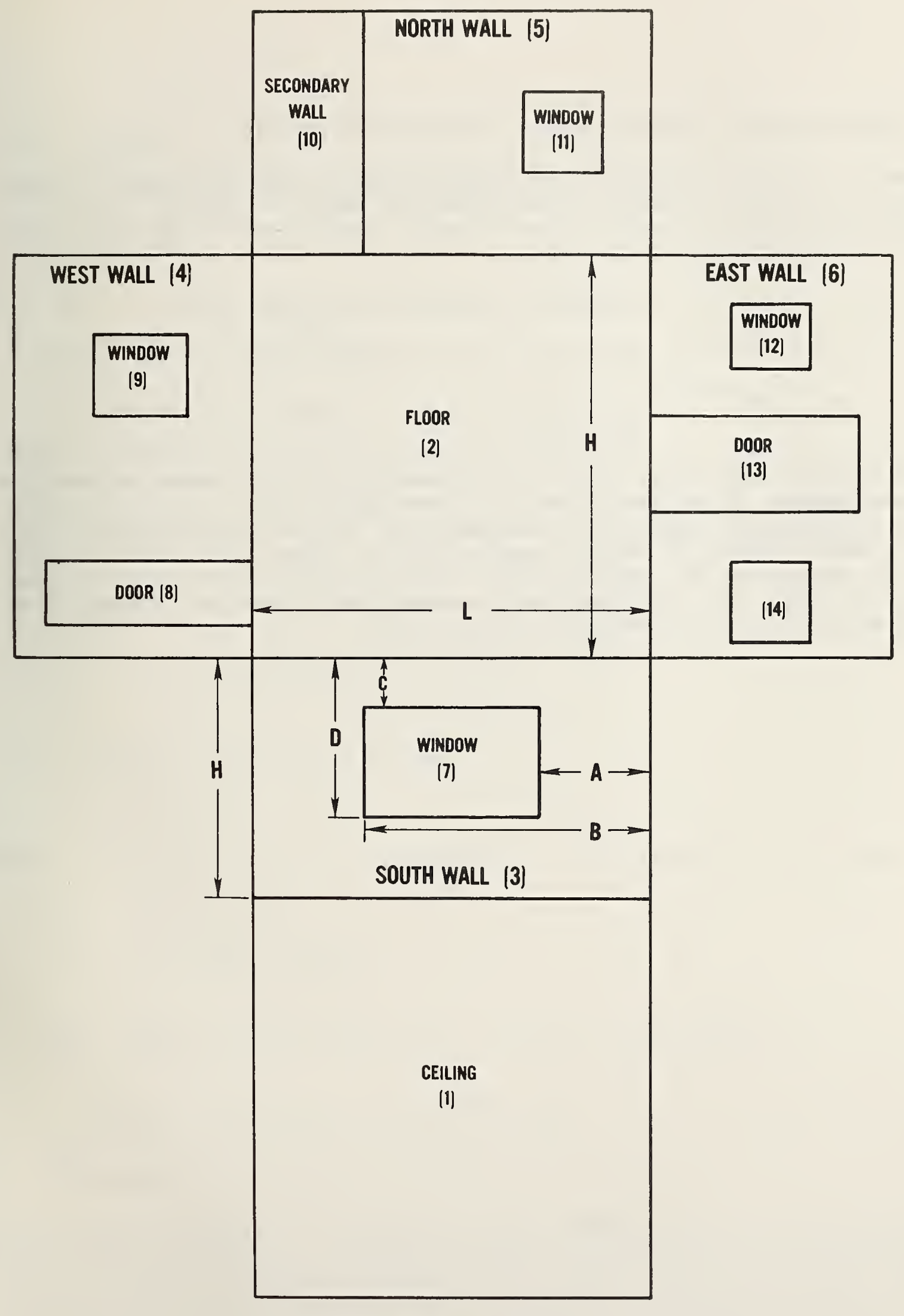

SAMPLE ROOM LAYOUT

Figure 1. Sample room layout. 


\section{CONVECTION HEAT TRANSFER BETWEEN ROOM SURFACES AND AIR}

Generally, the heat transfer between room surface and the air involves motion in the air due to difference in density and the action of gravity or natural convection. Natural convection heat transfer coefficients for air are defined [4] by the simplified relationships

$$
\begin{aligned}
& \mathrm{H}_{c}=0.19(\Delta \mathrm{T})^{0.33} \text {, horizontal heat flow to vertical plates } \\
& \mathrm{H}_{c}=0.22(\Delta \mathrm{T})^{0.33} \text {, heat flow up to or from horizontal plates (1b) } \\
& \mathrm{H}_{c}=0.11(\Delta \mathrm{T})^{0.33} \text {, heat flow down to or from horizontal plates (lc) }
\end{aligned}
$$

where $\Delta \mathrm{T}$ is assumed to be the absolute temperature difference between the air and the surface considered. These relationships make the computation more complicated because in the heat balance the temperatures of the surfaces and the air are unknowns and need to be determined. In the iterative technique this can be easily handled by assuming surface and air temperatures from the previous time period for the first iteration of present time step. In the present version of NBSLD, the convection heat transfer coefficients are assumed to be constants for the three directions of heat flow. 


\section{HEAT BALANCE}

At exterior facing surfaces the heat balance is given by

$$
Q_{R}^{m}+Q_{A}^{m}+Q_{O, t}^{m}-Q_{S}=0
$$

where

a) Incident solar radiation

$$
\mathrm{Q}_{\mathrm{R}}^{\mathrm{m}}=\alpha_{\mathrm{m}} \mathrm{I}_{\mathrm{t}}^{\mathrm{m}}
$$

b) Convection heat transfer from the outdoor air

$$
Q_{A}^{m}=H_{o, t}^{m}\left(T_{b, t}-T_{o, t}^{m}\right)
$$

c) Conduction heat flow at outdoor surface of building construction

$$
\begin{aligned}
Q_{o, t}^{m} & =Y_{1, k}^{m} T_{i, t}^{m}-Z_{1, k}^{m} T_{o, t}^{m}+\sum_{n=1}^{k} R_{n}^{m} Q_{o, t-n}^{m} \\
& +\sum_{n=2}\left(Y_{n, k}^{m} T_{i, t-n+1}^{m}-Z_{n, k}^{m} T_{o, t-n+1}^{m}\right)
\end{aligned}
$$

d) Long-wave radiation to the sky

$$
Q_{S}=2 \beta(10-C) \text {. }
$$

Solving for the outside surface temperature at time $t$ gives the relationship

$$
\begin{aligned}
& \mathrm{T}_{\mathrm{o}, \mathrm{t}}^{\mathrm{m}}=\mathrm{B}_{1} \mathrm{~T}_{\mathrm{i}, \mathrm{t}}^{\mathrm{m}}+\mathrm{B}_{2} \\
& B_{1}=Y_{1, k}^{m} /\left(H_{o, t}^{m}+Z_{1, k}^{m}\right) \\
& \left(H_{o, t}^{m}+z_{1, k}^{m}\right) B_{2}=\alpha I_{t}^{m}+H_{o, t}^{m} T_{b, t}^{m}+2 \beta(10-C)+\sum_{n=1}^{k} R_{n}^{m} Q_{o, t-n}^{m} \\
& +\sum_{n=2}\left(Y_{n, k}^{m} T_{i, t-n+1}^{m}-Z_{n, k}^{m} T_{o, t-n+1}^{m}\right) .
\end{aligned}
$$

The coefficients $B_{1}$ and $B_{2}$ are known for each time, $t$.

Equation (3) is solved for the outside surface temperature of a wall exposed to outdoor weather conditions. If the wall divides two rooms, then a proper heat balance is necessary at the surface of the other room, for which another definition for $B_{1}$ and $B_{2}$ must be determined. Similarly, proper heat balances must be performed for attic spaces and crawl spaces where appropriate definitions may be derived for the constants $B_{1}$ and $B_{2}$. It is not the purpose of this paper to propose algorithms for defining heat transfer in attic and crawl 
spaces. A model will be proposed in section 5 which will adequately define the external conditions as they affect the room heat balance, particularly in reference to comparison of various determination methods (such as found in NBSLD, BLAST, AND DOE-2).

The heat balance at a room surface is

$$
\begin{aligned}
H_{1, t}^{m}\left(T_{1, t}^{m}-T_{a, t}\right)+X_{1, k}^{m} T_{1, t}^{m}-Y_{1, k}^{m} T_{0, t}^{m}+\sum_{n=2}\left(X_{n, k}^{m} T_{1, t-n+1}^{m}\right. \\
\left.-Y_{n, k}^{m} T_{0, t-n+1}^{m}\right)+\sum_{n=1}^{k} R_{n}^{m} Q_{1, t-n}^{m}+S_{1, t}^{m}=0
\end{aligned}
$$

where

$$
H_{1, t}^{m}=\frac{H_{c 1}^{m}\left(T_{1, t}^{m}-T_{a, t}\right)+\sum_{n=1} \sigma F_{m, n}\left[\left(T_{1, t}^{m}+460\right)^{4}-\left(T_{1, t}^{n}+460\right)^{4}\right]}{\left(T_{1, t}^{m}-T_{a, t}\right)}
$$

Solving for the surface temperature $T_{1, t}^{m}$ in (4) gives

$$
\begin{aligned}
B_{3} T_{1, t}^{m}=H_{1, t}^{m} T_{a, t}+B_{4} \\
B_{3}=H_{1, t}^{m}+X_{1, k}^{m}-Y_{1, k}^{m} B_{1} \\
B^{4}=Y_{1, k}^{m} B_{2}+S_{1, t}^{m}-\sum_{n=2}\left(X_{n, k}^{m} T_{1, t-n+1}^{m}=T_{n, k}^{m} T_{0, t-n+1}^{m}\right) \\
=\sum_{n=1}^{k} R_{n}^{m} Q_{1, t-n}^{m}
\end{aligned}
$$

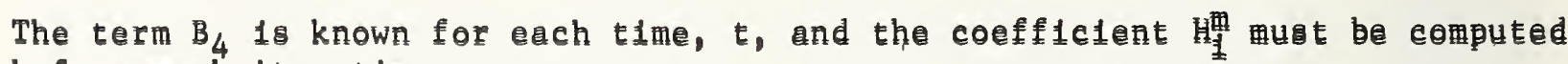
before elch iteration.

The heat balance for the room alr can be expresied by the following relationship

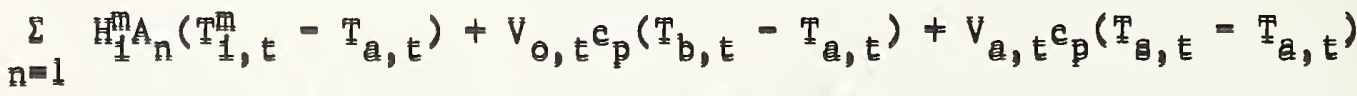

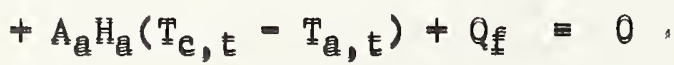

At the gurface of the room mal

$$
H_{a}\left(T_{e, t}-T_{a, t}\right)+\underset{n=1}{e}\left(X_{n, k}^{e} \neq z_{n, k}^{e}=2 \gamma_{n, k}^{e}\right) T_{e, t=n \neq 1}^{e} \equiv 0
$$

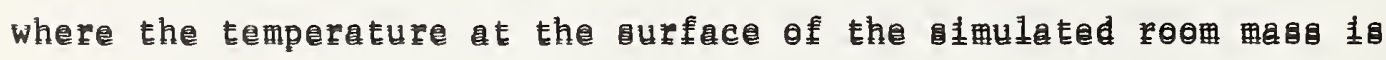




$$
\begin{aligned}
B_{5} T_{c, t} & =H_{a} T_{a, t}-B_{6} \\
B_{5} & =H_{a}+X_{1, k}^{c}+Z_{1, k}^{c}-2 Y_{1, k}^{c} \\
B_{6} & =\sum_{n=2}\left(X_{n, k}^{c}+Z_{n, k}^{c}-2 Y_{n, k}^{c}\right) T_{c, t-n+1}
\end{aligned}
$$

The temperature of the room air becomes

$$
\begin{aligned}
& B_{7} T_{a, t}=\sum H_{i}^{n} A_{n} T_{i, t}^{n}+B_{8} \\
& B_{7}=\sum_{n=1} H_{i}^{n} A_{n}+\left(V_{o, t}+V_{a, t}\right) c_{p}+\frac{A_{a} H_{a}}{B_{5}}\left(B_{5}-H_{a}\right) \\
& B_{8}=\left(V_{o, t} T_{b, t}+V_{a, t} T_{s, t}\right) c_{p}+Q_{f}+\frac{A_{a} H_{a} B_{6}}{B_{5}} .
\end{aligned}
$$

Constants $B_{5}, B_{6}, B_{7}$ and $B_{8}$ are computed once for each time, $t$.

Using (6) and (10), the surface temperatures and the room air temperature may be solved for by iteration where for the first iteration these temperatures are assumed to be the same as for the previous time, $t-1$, for a unit time interval. After each iteration, $H_{i, t}^{m}$ must be redetermined due to changes in $T_{i, t}^{m}$ and $\mathrm{T}_{\mathrm{a}, \mathrm{t}}$, and changes in $\mathrm{H}_{\mathrm{ci}}^{\mathrm{i}}$, from the relationships (la), ( $\left.1 \mathrm{~b}\right)$, or $(\mathrm{lc})$. $\mathrm{t}_{\text {The total }}$ number of iterations is to be determined by establishing conditions for the convergence of the iterative process. When adequate convergence is attained for $\mathrm{T}_{i, t}^{\mathrm{m}}$ and $\mathrm{T}_{\mathrm{a}}, \mathrm{t}$, then $\mathrm{T}_{\mathrm{m}, \mathrm{t}}^{\mathrm{m}}(3), \mathrm{T}_{\mathrm{c}, \mathrm{t}}(9), \mathrm{Q}_{i, t}^{\mathrm{m}}$ and $\mathrm{Q}_{\mathrm{o}, \mathrm{t}}^{\mathrm{m}}(2 \mathrm{c})$ are to be determined. $Q_{i, t}^{m^{a}, t}$ is the sum of the second, third, fourth and fifth terms of (4). 


\section{CONCLUSIONS}

The heat transfer algorithms presented in sections 2 and 3 of this report are intended to be used in part or whole for the purpose of determining heat exchange within a room. Although they represent an ideal case, they are probably the most exact of methods presented previously and could be used to compare other methods.

For comparing different analytical techniques dealing with heat exchange in a room, the effects of external and internal heat balance algorithms on the results should be distinguished. To perform such comparisons, a simplistic model is suggested, which simulates four wall surfaces, a flat roof and a floor raised from the ground level so that all six envelope surfaces are exposed to the environment. This model, which would be similar to vacation homes in some coastal regions, offers a somewhat realistic condition by which the use of available algorithms can be justified. With this model, comparisons of the method proposed in this paper can be made to other methods, particularly for geometrical and orientation considerations for the placement of windows, doors, etc., effect of internal mass, effect of variation in the surface coefficients of heat transfer, and effect of surface emittance and reflectance (radiosity).

The iterative solution for the surface and air temperature offers a method by which the more exact algorithms may be used whereby a computation time savings is evident when compared to other methods of solution. A computer program using this feature is possible. Use of this feature on NBSLD was not attempted because this was not within the scope of this study. 


\section{References}

1. T. Kusuda, Fundamentals of Building Heat Transfer, J. Research, Natl. Bur. Stds., Vol. 82, No. 2, 1977.

2. T. Kusuda, NBSLD, the Computer Program for Heating and Cooling Loads in Buildings. BSS 69, Nat1. Bur. Stds., July 1976, pp 48-59a, 79-8la, 94-99a, 45-51c.

3. J. A. Wiebelt, Engineering Radiation Heat Transfer. Holt, Rinehart and Winston, 1966.

4. Handbook of Fundamentals, ASHRAE, New York, 1977. 



\section{Appendix A}

Subroutine ROOMZ - to compute the radiation shape factors and the radiosity shape factors for a room in the shape of a rectangular parallelepiped. The walls of the room may have up to 24 rectangular shapes on them which may represent windows, doors and/or secondary walls. The first 3 inputs (Lines 13, 24, and 58 of listing) are identical to Data Sheets 12 and 13 of [2]. At line 62 of the listing, 5 numbers are input to the subroutine, if other than the primary walls, ceiling, or floor are to be considered; namely,

1. Width of the window door or secondary wall

2. Height of above

3. Distance from left corner of wall to closest side

4. Height from floor to bottom of rectangle

5. Emittance of surface (needed for all surfaces).

With the above information, the radiation shape factors are calculated using the algorithms found in [2], pages 48a-58a. At line 280, the radiation shape factors have been computed and stored in the array $F(M, N)$. Radiosity shape factors are then computed and stored in the array $\operatorname{SF}(M, N)$ (1ine 307). 
ลิ

ปั

它藏.

กิ

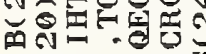

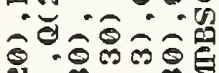

สิ

《ส

-

글

xิ-

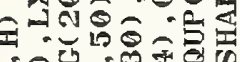

1

둘

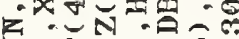

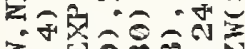

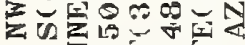

क० 0.5

ス守こ一ำ

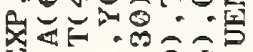

ㄱ. 응

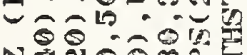

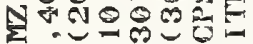

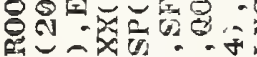

国

1

in

霓

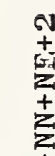

堅告

ำ3

$\frac{\pi}{4}$

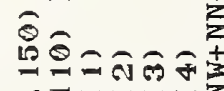

Qิ-

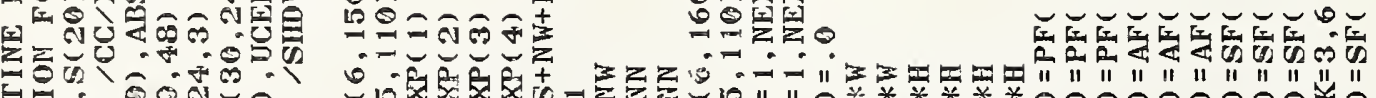

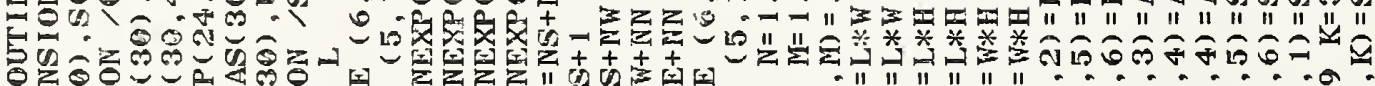

的国国

00000

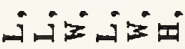

$\dot{\theta} \dot{\theta} \dot{\theta} \theta$

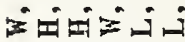

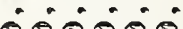

$00000 \quad 4$

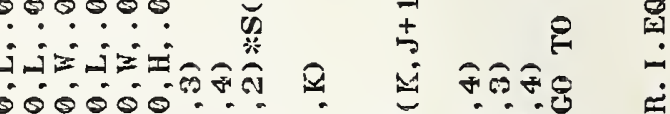

I काष

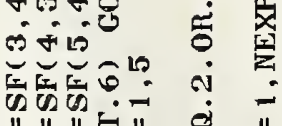
" "I"

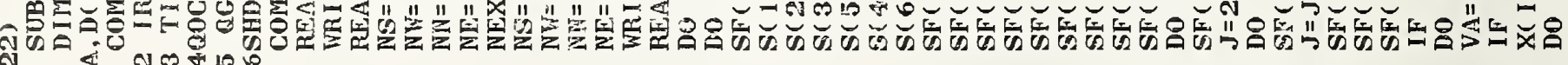

N

ลิ हैं 

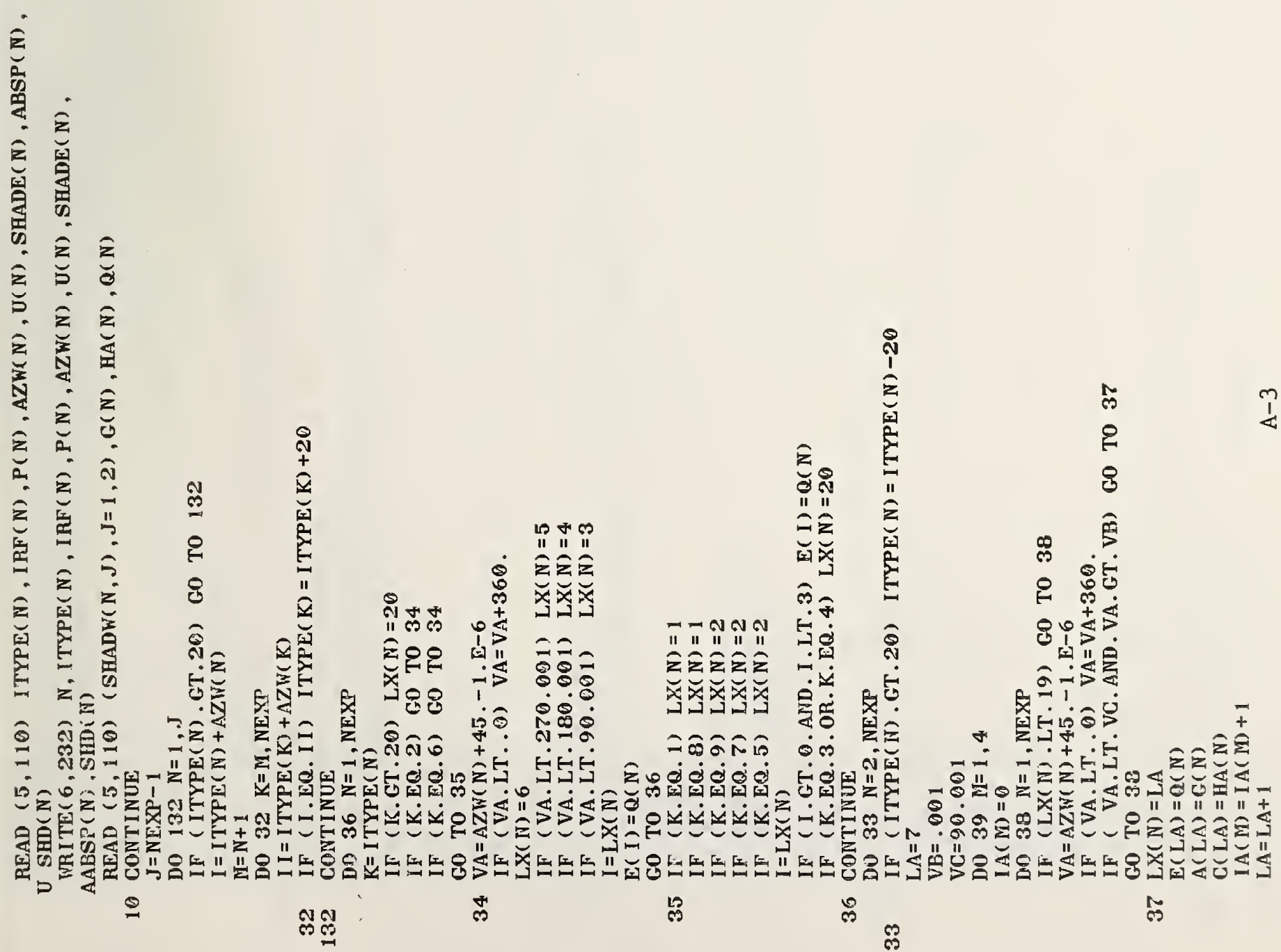


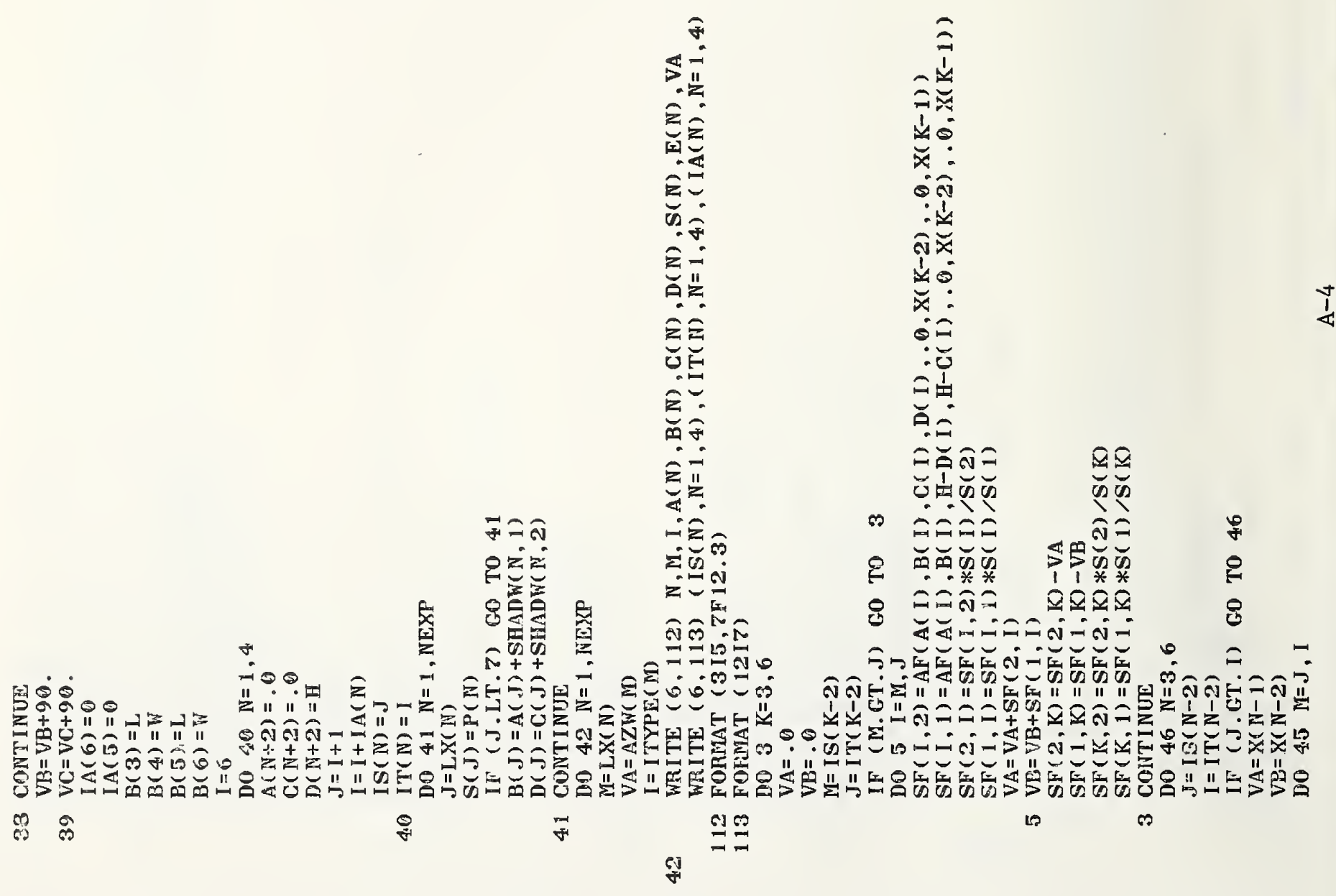




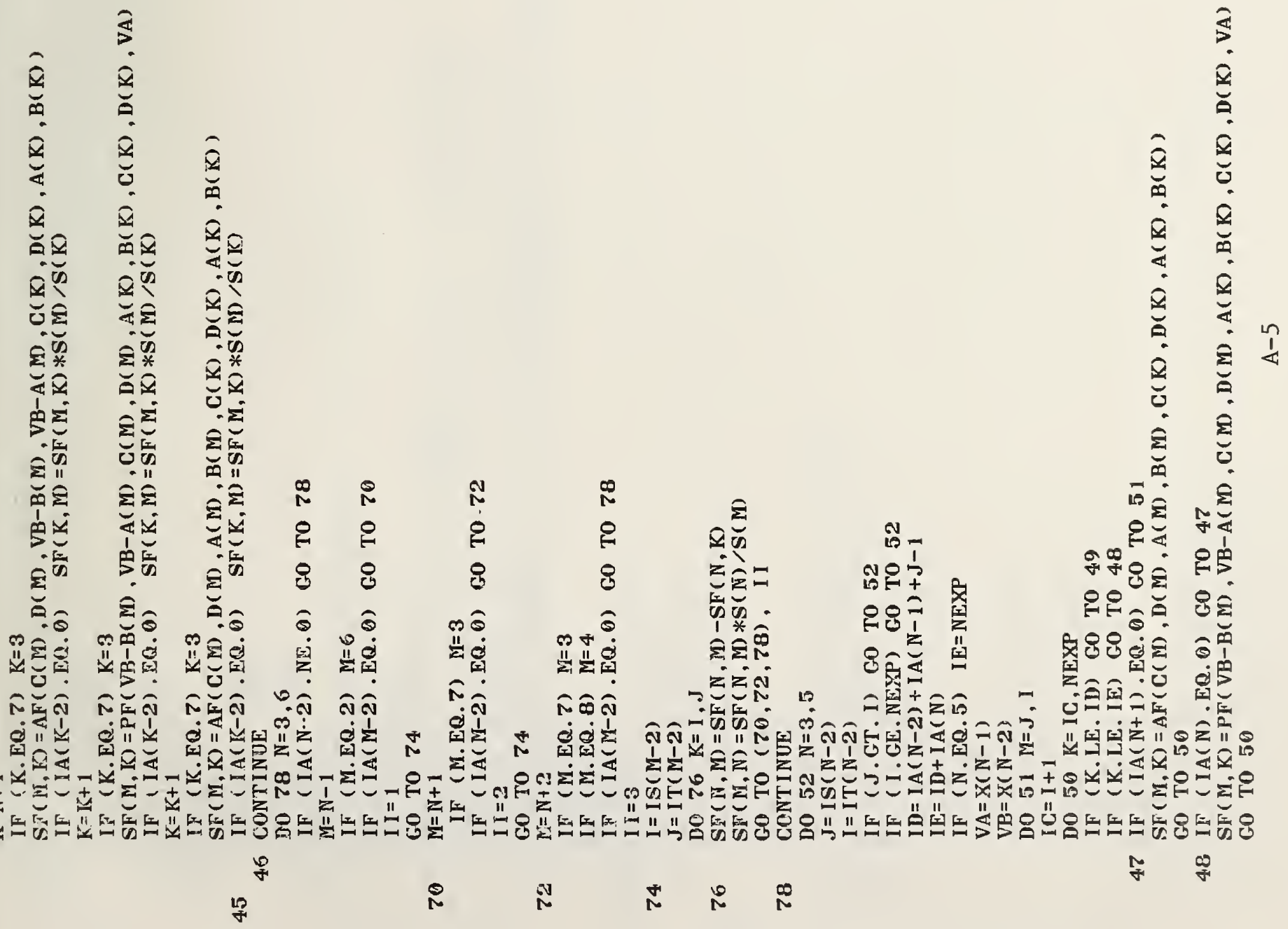




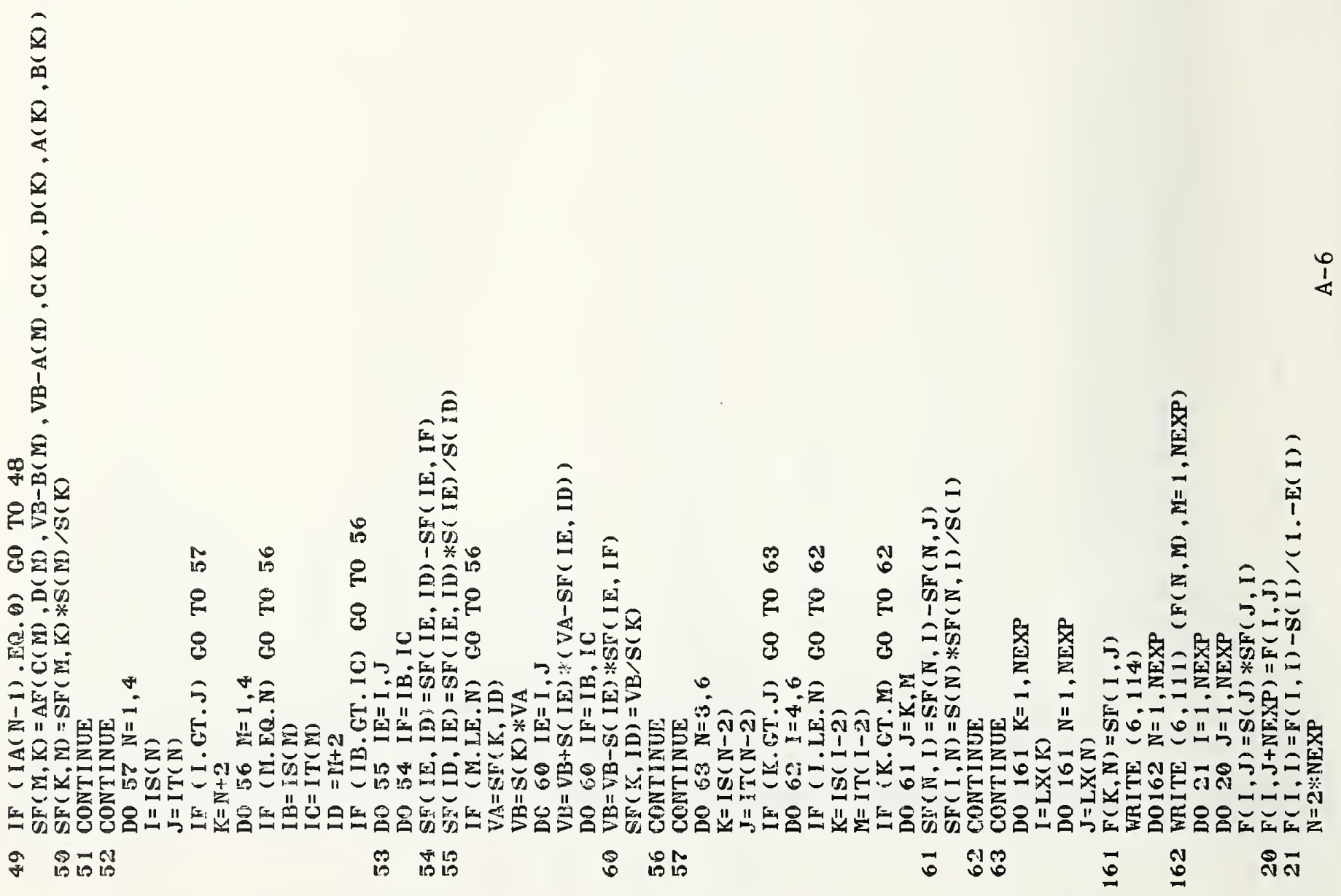




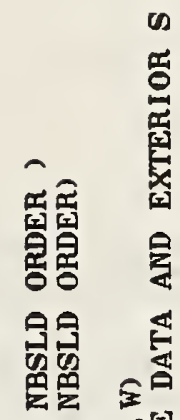

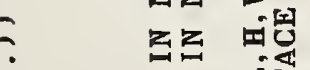

1 11 退

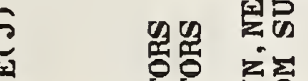

* हुํㅕㅇ

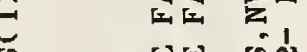

되데

题 10

兒思 是

그일 을

惯罗

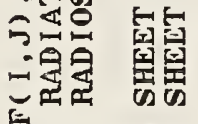

के

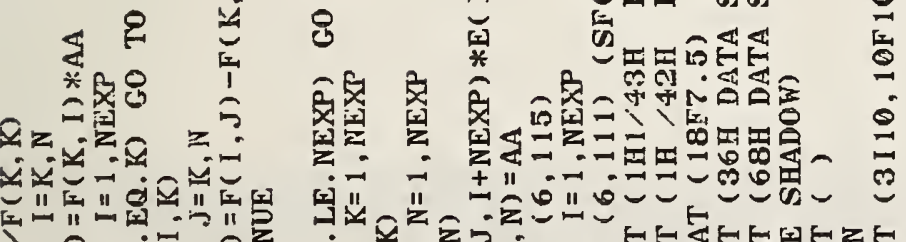

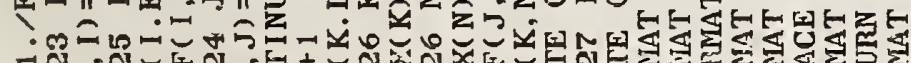

I

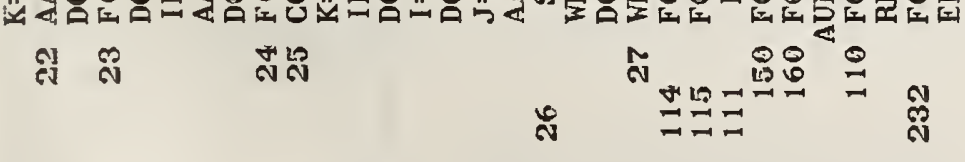

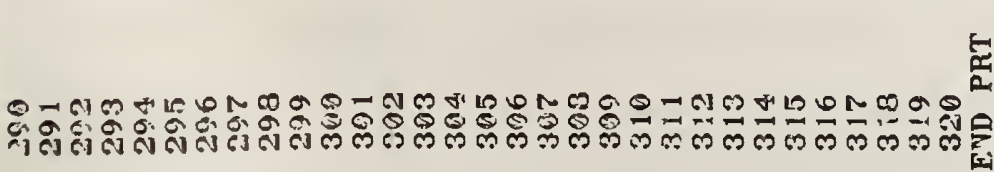


4. TITLE AND SUBTITLE

SINGLE-ROOM HEAT BALANCE FOR BUILDING HEAT TRANSFER

5. $\operatorname{AUTHOR}(S)$

Bradley A. Peavy

6. PERFORMING ORGANIZATION (If joint or other than NBS, see instructlons)

7. Contract/Grant No.

NATIONAL BUREAU OF STANDARDS

DEPARTMENT OF COMMERCE

WASHINGTON, D.C. 20234

\section{SFONSORHG ORGANIZATION NAME ANO COMPLETE ADDRESS (Street, CHY, StOTE, ZIF)}

NBS and

Department of Energy

Passive and Hybrid Solar Energy Division

Office of Solar Heat Technologies

Washington, DC 20585

10. SUPPLEMENTARY NOTES

[Document describes a computer program; SF-185, FIPS Software Summary, is attached.

11. ABSTRACT (A 200-word or less factual summary of most significant information. If document includes a significant bibliography or literature survey, mention it here)

A single-room heat balance has been developed to provide a more precise computational tool. The primary purpose for this tool is to evaluate the effects of approximations presently used in computer programs on the determination for building heating and cooling loads. Specific algorithms to be incorporated in the room heat balance concern radiosity shape factors, temperature difference dependent convection heat transfer coefficients, simulated room mass, and an iterative methodology for solution of room temperatures.

12. KEY WORDS (Six to twelve entries; alphabetical order; capitalize only proper names; and separate key words by semicolons) building heating/cooling loads; heat balance for a single room; heat transfer; radiosity shape factors

\section{AVAILABILITY}

X] Unlimited

For Official Distribution. Do Not Release to NTIS

Order From Superintendent of Documents, U.S. Government Printing Office, Washington, D.C. 20402.

[X] Order From National Technical Information Service (NTIS), Springfield, VA. 2216I
14. NO. OF

PRINTED PAGES

22

15. Price

$\$ 5.00$ 

